\title{
Pengembangan Model Permainan untuk Meningkatkan Perseptual Motorik dan Perilaku Sosial Siswa Sekolah Dasar Kelas Bawah
}

\author{
Nurul Fajar Muslimah Ningrum ${ }^{1}$ *, Pamuji Sukoco ${ }^{1}$ \\ ${ }^{1}$ Program Studi Ilmu Keolahragaan, Program Pascasarjana, Universitas Negeri Yogyakarta. Jalan \\ Colombo No. 1, karangmalang, Yogyakarta, 55281, Indonesia \\ * Corresponding Author. Email: nurul.fajar35@yahoo.com
}

Received: 22 January 2016; Accepted: 3 October 2017

\begin{abstract}
Abstrak
Penelitian ini bertujuan untuk menghasilkan model permainan untuk meningkatkan perseptual motorik dan perilaku sosial siswa sekolah dasar kelas bawah yang sesuai, layak, dan efektif. Model permainan ini diharapkan mampu mengembangkan aspek afektif, kognitif, dan psikomotor, serta dapat dipergunakan oleh guru dalam melaksanakan kegiatan pembelajaran pendidikan jasmani. Ujicoba skala kecil dilakukan terhadap 27 siswa SD N Ambarukmo. Ujicoba skala besar dilakukan terhadap 32 siswa SD N Ngringin dan 34 siswa SD N Puren. Instrumen yang digunakan untuk mengumpulkan data adalah pedoman pengamatan (observasi), pedoman wawancara, catatan lapangan, skala nilai, lembar penilaian uji efektifitas dan penilaian hasil belajar. Teknik analisis data yang dilakukan yaitu analisis deskriptif kuantitatif dan analisis deskriptif kualitatif. Hasil penelitian berupa model permainan, yang berisikan 6 model permainan, yaitu: (1) permainan karung berantai, (2) permainan egrang berantai, (3) permainan engklek berantai, (4) permainan balok berantai, (5) permainan kelereng berantai, (6) permainan ban berantai. Model permainan disusun dalam bentuk buku pedoman dan dituangkan dalam bentuk DVD. Berdasarkan hasil penilaian para ahli materi dan praktisi, dapat ditarik kesimpulan bahwa model permainan untuk meningkatkan perseptual motorik dan perilaku sosial siswa sekolah dasar kelas bawah yang didesain berkategori baik, sehingga model permainan telah sesuai, layak, dan efektif untuk digunakan.
\end{abstract}

Kata Kunci: model permainan, perseptual motorik, perilaku sosial, siswa sekolah dasar kelas bawah

\section{Developing Game Model to Improve Perceptual Motor and Social Behavior of Lower Levels Students}

\begin{abstract}
This study aims to produce a game model for increasing perceptual motor and social behavior under class elementary school students which is appropriate, suitable, and effective. The game model is expected to be able to develop effective, cognitive, and psychomotor aspects, also can be used by teacher in learning process of physical education. Small-scale trial was conducted to 27 students in SD N Ambarukmo. A large trial was conducted to 32 students in SD N Ngringin and 34 students in SD $N$ Puren. The instrument used to collect data were observation guide (observation), interviews guide, field notes, scale values, assessment sheets, an effectiveness test and assessment of the learning outcomes. The data were analyzed using the quantitative descriptive analysis and qualitative descriptive analysis. The results of the research is a game model, including six game models, namely: (1) chained coarse bag game, (2) chained egrang game, (3) chained engklek game, (4) chained block game, (5) chained marble game, (6) chained tube game. The game model is arranged in a guide book and DVD. Based on the evaluation of experts and practitioners, it can be concluded that the game model to increase perceptual motor and social behavior under class elementary school students is categorized good, so that the a game model that has been developed is suitable, effective, and appropriate for use.
\end{abstract}

Keywords: game model, perceptual motor, social behavior, under class elementary school students

How to Cite: Ningrum, N., \& Sukoco, P. (2017). Pengembangan model permainan untuk meningkatkan perseptual motorik dan perilaku sosial siswa sekolah dasar kelas bawah. Jurnal Keolahragaan, 5(2), 171-182. doi:http://dx.doi.org/10.21831/jk.v5i2.7905

Permalink/DOI: http://dx.doi.org/10.21831/jk.v5i2.7905 


\section{PENDAHULUAN}

Pendidikan jasmani pada dasarnya merupakan bagian integral dari sistem pendidikan secara keseluruhan. Rosdiani (2012, p. 22) menyatakan dalam proses pembelajaran pendidikan jasmani guru diharapkan mengajarkan berbagai keterampilan gerak dasar, teknik dan stretegi permainan dan olahraga, internalisasi nilai-nilai (sportifitas, jujur, kerjasama, dan lain-lain) serta pembiasaan pola hidup sehat. Oleh karena itu, dalam pembelajaran pendidikan jasmani seorang guru sebelum melakukan pembelajaran dilaksanakan terlebih dahulu berkewajiban untuk membuat suatu rencana. Mohnsen (2008, p. 133) pencapaian yang harus dicapai guru pendidikan jasmani yaitu mempunyai kesadaran menyeluruh tentang dasar-dasar pendidikan jasmani dan kesadaran yang luas terhadap prinsip dan teoriteori.

Gambaran umum tentang efektivitas mengajar ditandai oleh gurunya yang selalu aktif dan siswa secara konsisten aktif belajar. Pembelajaran yang efektif sangat diperlukan dalam mencapai tujuan pembelajaran yang diinginkan. Agar pembelajaran dapat berjalan efektif, maka guru harus dapat mengelola kelas dengan baik. Menciptakan kondisi belajar mengajar yang efektif sedikitnya ada lima jenis variabel yang menentukan keberhasilan belajar siswa, yaitu (1) melibatkan siswa secara aktif dan memaksimalkan jam pembelajaran penjas, (2) menarik minat dan perhatian siswa artinya seorang guru perlu menarik minat dan perhatian siswa dengan memberikan variasi bentuk-bentuk pembelajaran, (3) membangkitkan motivasi siswa, (4) prinsip individualitas, dan (5) peragaan dalam pengajaran artinya guru perlu menggunakan media/alat yang berguna untuk menstrasfer materi-materi yang akan diajarkan (Usman, 2010, p. 21).

Pengembangan gerak merupakan salah satu bagian terpenting dari tujuan dalam pelaksanaan pembelajaran pendidikan jasmani, salah satu hal yang perlu mendapatkan perhatian bagi siswa di sekolah dasar khususnya kelas bawah adalah perkembangan gerak yang mengandung unsur-unsur kemampuan perseptual motorik.

Pada dasarnya perseptual motorik merupakan kemampuan individu untuk menerima, menginterpretasikan, dan memberikan reaksi dengan tepat kepada sejumlah rangsangan yang datang kepadanya, tidak hanya dari luar dirinya tetapi juga dari dalam. Gabbard, LeBlanc, \& Lowy (1994, pp. 279-322) menyatakan unsur- unsur perseptual motorik meliputi: kesadaran tubuh, kesadaran ruang, keasadaran arah, kesadaran keseimbangan, koordinasi, kesadaran tempo, kesadaran pengelihatan, kesadaran perasa, kesadaran pendengaran. Kemampuan perseptual motorik memiliki peranan yang sangat penting bagi siswa. Bukti penelitian menunjukan bahwa penguasaan psikomotor atau kognitif mengandung unsur keterlibatan perseptual motorik. Selain itu, perseptual motorik memiliki hubungan terhadap keberhasilan dibidang akademik, kehidupan sehari-hari dan belajar gerak.

Tseng \& Murray (1994, p. 20) menyatakan to write legibly depends on the integrity of several perceptual motor subskills. The subskills that numerous researchers have identified include visual perception, hand-eye coordination, visualmotor integration, kinesthetic perception, fine motor praxis, and manual dexterity. Berdasarkan pendapat tersebut disimpulkan ada hubungan perseptual motorik dengan kemampuan menulis, untuk menulis dengan jelas tergantung pada integritas beberapa sub-keterampilan perseptual-motor. Sub keterampilan yang banyak dari hasil penelitian mengidentifikasi termasuk persepsi visual, koordinasi tanganmata, penggabungan motorik visual, persepsi kinestetik, baik praksis motorik, dan ketangkasan tangan.

Rosalie \& Müller (2012, p. 413) menyatakan kemampuan untuk berhasil menerapkan dan belajar beradaptasi dalam menghadapi variasi lingkungan yang berubah-ubah adalah dasar hampir semua aktivitas manusia, hal ini sangat penting dalam kaitannya dengan keterampilan perseptual-motor, karena perseptual-motor dilakukan berdasarkan kebutuhan untuk mencapai tujuan. Misalnya, tugas sehari-hari, seperti mengemudi, membutuhkan poros penggerak atau penunjuk untuk menggambarkan pengalaman belajar sebelumnya seperti permukaan jalan, kondisi lalu lintas, penumpang, perilaku pejalan kaki untuk berhasil dan kendaraan aman bergerak dalam berbagai situasi. Demikian pula, dalam olahraga, individu berlatih perseptualmotor mempersiapkan pencapaian tujuan yang lebih efisien dan sukses selama kompetisi, seperti memblok pukulan lawan/tendangan, menyerang, melempar, menendang bola, mengatasi/mencegat lawan dalam berbagai situasi, tergantung pada kebutuhan dan kendala dari konteks.

Gallahue, Ozmun, \& Goodway (2012, p. 275) menyatakan perseptual motorik khususnya kesadaran/kesadaran arah penting untuk orang 
tua dan guru karena merupakan komponen dasar untuk belajar bagaimana membaca. Anak-anak yang tidak sepenuhnya membangun/mengembangkan kesadaran arah (directionality) akan sering menghadapi kesulitan dalam membedakan antara berbagai huruf abjad. Misalnya, huruf b, d, p, dan q semua sama. Satu-satunya perbedaan terletak pada arah "bola" dan "tongkat" yang membentuk huruf. Anak tanpa sepenuhnya dibangun kesadaran/kesadaran arah (directionality) menemukan kesulitan dalam membedakan antara beberapa huruf abjad. Seluruh kata-kata bahkan mungkin dapat diubah. Membangun kesadaran arah adalah proses perkembangan yang bergantung pada pematangan dan pengalaman. Pada usia 4 dan 5 tahun jika mengalami kebingungan dalam arah adalah hal yang normal, sehingga yang perlu diberikan perhatian adalah anak berusia 6 dan 7 tahun yang terus-menerus mengalami masalah kesadaran/kesadaran arah, karena usia ini adalah waktu ketika sebagian besar sekolah biasanya memulai pengajaran dalam membaca (Gallahue et al., 2012, p. 275).

Kenyataan di lapangan berdasarkan hasil observasi, wawancara, dan catatan lapangan dalam pendidikan jasmani yang berhubungan dengan perseptual motorik masih sering diabaikan dengan pembelajaran yang klasik baik untuk pembelajaran gerak atau permainan, meskipun secara teoritis, hasil penelitian menunjukan perseptual motorik merupakan hal yang penting dalam perkembangan siswa. Guru penjas lebih menitik beratkan kepada gerak/psikomotor semata dan perseptual motorik belum menjadi pertimbangan dalam proses belajar motorik, padahal psikomotor mengandung unsur-unsur perseptual motorik di dalamnya, apa yang akan terjadi ketika seorang guru penjas tidak memberikan perhatian terhadap perseptual motorik anak? berdasarkan pendapat diatas akan terjadi pertumbuhan yang kurang bagus, perkembangan gerak yang kurang optimal, dan fungsi kognisi yang kurang optimal, hal tersebut ada yang berpengaruh langsung dan tidak langsung.

Pertama, ketika perseptual motorik kurang baik maka anak akan tumbuh kurang baik. Kesadaran dari pernyataan ini adalah ketika anak memiliki perseptual motorik yang kurang baik hal ini berkaitan dengan kesempatan untuk mempelajari gerak yang baru dan kesempatan untuk bergerak. Perseptual motorik yang kurang maka kemampuan untuk belajar gerak menjadi kurang. Ketika anak kurang kesempatan belajar maka penguasaan gerak juga kurang. Kurangnya penguasaan gerak akan membatasi anak dalam bersosialisasi, serta membuat anak merasa kurang percaya diri sehingga akan mudah merasa minder, kurang mampu untuk mengembangkan perilaku sosialnya seperti untuk bekerjasama, bahkan terkadang menjadi bahan ejekan temantemannya.

Kedua, ketika perseptual motorik kurang maka perkembangan gerak kurang optimal. Contoh: saat melakukan keterampilan menangkap, ketika anak mendapat lemparan bola, anak akan berpikir apa yang harus dilakukan, kemana arah bola tersebut dan bagaimana posisi yang tepat, anak yang memiliki kesadaran arah yang kurang akan merasa kesulitan menempatkan posisi yang tepat untuk menangkap bola tersebut, sehingga terkadang bola yang datang gagal ditangkap atau bahkan terkadang mengenai wajah.

Ketiga, ketika perseptual motorik kurang maka fungsi kognisi kurang optimal misalnya dalam melakukan aktivitas gerak bermain, dalam melaksanakan permainan anak harus mempunyai kemampuan memahami peraturan, teknik, strategi, taktik, dan pengambilan keputusan, ketika seorang anak memiliki perseptual motorik yang kurang maka akan mengalami kesulitan untuk menggabungkan kemampuan ini.

Peran pendidikan jasmani sangat penting dalam hal ini, sehingga perlu adanya perhatian khusus terhadap keterlibatan unsur-unsur perseptual motorik dalam psikomoto/gerak. Guru perlu merancang sebuah model pembelajaran yang mampu memberikan fasilitas kepada siswa untuk mengembangkan kemampuan perseptual motorik. Pemilihan bentuk pembelajaran dan materi yang tepat sangat penting dalam mata pelajaran penjas, dalam kurikulum KTSP salah satu bentuk pembelajaran yang dapat digunakan yaitu permainan dengan materi yang dapat dimanfaatkan adalah materi jalan, lari, dan lompat. Permainan merupakan salah satu bentuk pembelajaran yang bertujuan agar pembelajaran lebih menarik dan membuat siswa senang untuk melakukan gerak dasar. Juniarta \& Siswantoyo (2014, p. 90) menyatakan model bermain merupakan upaya untuk memberikan variasi permainan yang dapat menarik minat anak.

\section{METODE}

Penelitian ini merupakan penelitian pengembangan (research and development). Penelitian ini dilakukan untuk mengembangkan model permainan untuk meningkatkan persep- 
tual motorik dan perilaku sosial, serta hasil pengembangan model permainan akan dilakukan uji validasi (uji lapangan) terhadap produk hasil pengembangan dengan harapan agar diperoleh model permainan: (1) sesuai dengan karakteristik perkembangan gerak lokomotor (jalan, lari, dan lompat) untuk siswa sekolah dasar kelas bawah, (2) layak dari segi isi materi, kesesuaian tujuan, sarana dan prasarana, bahasa, format penulisan, serta mudah dilaksanakan, dan (3) efektif untuk meningkatkan perseptual motorik dan perilaku sosial siswa sekolah dasar kelas bawah.

Prosedur pengembangan dalam penelitian ini mengadopsi dari tahapan penelitian pengembangan Gall, Gall, \& Borg (2007, pp. 570-572) meliputi: (1) penelitian dan pengumpulan informasi, (2) perencanaan, (3) mengembangkan produk awal, (4) pengujian lapangan utama, (5) revisi produk utama, (6) uji coba lapangan utama, (7) revisi produk secara operasional, (8) uji lapangan secara operasional, (9) revisi produk akhir, dan (10) desiminasi dan implementasi. Berdasarkan pendapat tersebut dalam penelitian ini dalam prosedur pengembangannya dilakukan modifikasi sesuai dengan kendala dan kondisi, meliputi: (1) studi literatur dan penelitian yang relevan, (2) studi pendahuluan, (3) mengembangkan produk awal, (4) validasi ahli dan revisi, (5) uji coba lapangan skala kecil dan revisi, (6) uji coba lapangan skala besar dan revisi, (7) pembuatan produk final, dan (8) uji efektifitas produk/uji lapangan secara operasional.

Uji Coba dilakukan dengan tujuan untuk menyempurnakan model permainan dengan mempraktekan secara langsung di lapangan. Uji coba produk dilakukan sebanyak tiga kali yaitu uji coba skala kecil, uji coba skala besar, dan uji efektifitas.

Subjek coba dalam penelitian ini adalah siswa sekolah dasar kelas bawah khususnya kelas I (satu). Tempat penelitian dibatasi pada Sekolah Dasar yang berada di Kecamatan Depok, Kabupaten Sleman. Uji coba produk skala kecil melibatkan siswa kelas I (satu) sebanyak 27 siswa dari Sekolah Dasar Negeri Ambarukmo, sedangkan uji coba produk skala besar melibatkan siswa kelas I (satu) sebanyak 32 siswa dari Sekolah Dasar Negeri Ngringin dan siswa kelas I (satu) sebanyak 34 siswa dari Sekolah Dasar Negeri Puren.

Jenis data dalam penelitian ini terdiri atas dua jenis data, yaitu data kualitatif dan data kuantitatif. Data kualitatif berasal dari: (a) hasil wawancara dalam studi pendahuluan dengan guru pendidikan jasmani, serta observasi dan catatan lapangan dalam proses pembelajaran pendidikan jasmani di Sekolah Dasar, (b) data masukan dan hasil revisi dari ahli materi dan praktisi. Sedangkan, data kuantitatif berasal dari: (a) penilaian ahli materi dan praktisi terhadap penyusunan draf model awal permainan, (b) penilaian ahli materi dan praktisi terhadap model permainan dalam uji coba produk skala kecil dan uji coba produk uji skala besar, dan (c) penilaian dari uji efektivitas terhadap model permainan.

\section{Teknik dan Instumen Pengumpulan Data}

Penelitian dan pengembangan ini menggunakan tiga tahap dalam pengumpulan data yaitu tahap pra pengembangan, tahap pengembangan dan tahap pasca pengembangan.

\section{Tahap Pra Pengembangan}

Tahap pertama adalah pra pengembangan, teknik pengumpulan data menggunakan observasi di lapangan, wawancara, catatan lapangan, serta studi dokumentasi. Pada tahap pra pengembangan didasari studi pendahuluan untuk mengetahui aspek permasalahan dan kebutuhan yang ada di lapangan. Selanjutnya dari permasalahan dapat diidentifikasi dan ditelusuri akan kebutuhan yang diperlukan dalam proses pembelajaran pendidikan jasmani di Sekolah Dasar.

\section{Tahap Pengembangan}

Tahap kedua adalah tahap pengembangan, pada tahap ini teknik pengumpulan data yang digunakan untuk mengevaluasi model pada saat validasi dan uji coba model, dalam hal ini yang bertindak sebagai observator adalah para ahli materi dan praktisi. Adapun teknik yang digunakan adalah skala nilai. Skala nilai ini digunakan untuk menilai atau mengobservasi kelayakan model permainan. Skala nilai yang digunakan dalam penelitian dan pengembangan menggunakan skala guttman. Sugiyono (2010, p. 169) menyatakan skala pengukuran dengan tipe ini, akan didapat jawaban yang tegas yaitu "ya-tidak", "benar-salah", "pernah-tidak pernah", "positif-negatif" dan lain-lain. Data yang diperoleh dapat berupa data interval atau rasio dikhotomi (dua alternatif).

\section{Tahap Pasca Pengembangan}

Tahap ketiga adalah tahap pasca pengembangan, tahap ini merupakan uji efektifitas 
produk akhir yang sudah menjadi produk pengembangan final. Produk akhir diuji efektifitas dengan penerapan langsung di la-pangan kepada siswa dan di amati menggunakan instrumen pengamatan yang mengarah pada tujuan. Teknik pengumpulan data yang digunakan untuk mengukur ketercapaian hasil belajar siswa dan respon siswa terhadap model permainan. Teknik yang digunakan adalah observasi siswa melalui rubrik penilaian hasil belajar siswa yang meliputi penilaian aspek afektif (perilaku sosial), aspek kognitif, dan aspek psikomotor (perseptual motorik), serta kuisioner terhadap respon siswa.

\section{Teknik Analisis Data}

Analisis Uji Validitas

Instrumen yang digunakan dalam penelitian ini sebelum digunakan divalidasi oleh ahli instrumen. Sugiyono (2010, p. 173) menyatakan instrumen yang valid berarti instrumen tersebut dapat digunakan untuk mengukur apa yang seharusnya diukur. Validitas suatu instrumen menyatakan derajat yang menunjukkan suatu instrumen mengukur apa yang akan diukur. Validitas logik mencakup validitas isi yang penentuannya didasarkan atas pertimbangan dari para pakar atau ahli. Stromberg \& Olson (Ayre \& Scally, 2014, p. 79) menyatakan validasi Isi mengacu pada proses yang bertujuan untuk memberikan jaminan/keyakinan bahwa instrumen (checklist, kuesioner, atau skala) langkahlangkah daerah isi tersebut diharapkan untuk mengukur.

Validitas isi menunjukkan suatu tes mengukur cakupan substansi yang ingin diukur. Validitas isi dihitung dengan menggunakan rasio validitas isi (Content Validity Ratio atau CVR). Lawshe (Azwar, 2003, p. 135) merumuskan Content Validity Ratio (CVR) yang dapat digunakan untuk mengukur validitas isi item-item berdasarkan data empirik, aitem dinilai esensial atau penting bilamana aitem tersebut dapat merepresentasikan dengan baik tujuan pengukuran.

Nilai CVR digunakan untuk menguji validitas dari tiap butir pertanyaan, sedangkan Content Validity Index (CVI) digunakan untuk menguji validitas secara keseluruhan. Allahyari, Rangi, Khosravi, \& Zayeri (2009, p. 10) menyatakan bahwa the content validity index (CVI) is simply a mean of the CVR values of items retained in the validated procedure, model, test, or format. Content Validity Index
(CVI) ini merupakan rata-rata nilai CVR yang dipertahankan dalam prosedur, model, tes, atau format divalidasi. Content Validity Index (CVI) digunakan untuk menghitung rata-rata dari nilai CVR yang telah memenuhi persyaratan minimum dan dianggap penting. Berikut ini rumus dari Content Validity Ratio atau CVR (Brinkman, 2009, p. 47).

$$
C V R=\frac{n e-\frac{N}{2}}{\frac{N}{2}}
$$

Keterangan:

ne: jumlah panelis yang menjawab "penting atau ya"

$\mathrm{N}$ : jumlah total panelis

Azwar (2003, p. 135) menyatakan angka CVR bergerak antara -1.00 sampai dengan +1.00 dengan CVR $=0,00$ berarti bahwa $50 \%$ dari panelis atau responden dalam panel menyatakan aitem adalah esensial dan karenanya valid. Selain CVR sebagai statistik validitas isi aitem, kemudian dapat pula dihitung statistik CVI (Content Validity Indeks) yang merupakan indikasi validitas isi tes. CVI adalah rata-rata dari CVR semua aitem.

$$
\mathrm{CVI}=\left(\sum \mathrm{CVR}\right) / \mathrm{k}
$$

\section{Keterangan:}

$\mathrm{k}$ : banyaknya aitem

Analisis Uji Reliabilitas

Reliabilitas merupakan konsistensi nilai yang diperoleh saat pengukuran tersebut digunakan. Reliabilitas adalah konsistensi tes. Sebuah tes yang dapat diandalkan harus mempunyai hasil kurang lebih sama tanpa memedulikan jumlah waktu yang diberikan. Dalam penelitian dan pengembangan ini untuk mencari reliabiltas menggunakan formula Spearman-Brown (Split Half).

Azwar (2007, p. 64) menyatakan formula spearman brown merupakan sebuah formula yang sangat populer untuk estimasi reliabilitas tes yang dibelah menjadi dua bagian yang relatif paralel satu dengan yang lain, pembelahan dilakukan dengan cara membelah antara gasal genap atau cara matched random subsets. Adapun rumus formula spearman brown, sebagai berikut: 


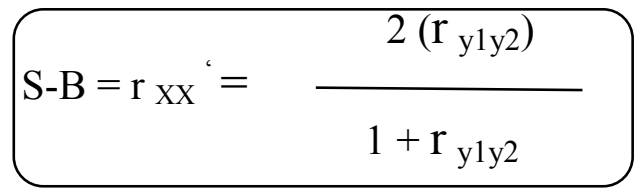

Keterangan:

$\mathrm{r}_{\mathrm{Xx}}{ }^{1} \quad$ : Koefisien reliabilitas Spearman Brown

$\mathrm{r}_{1.2} \quad$ : Koefisien korelasi antara kedua belahan (Azwar, 2007, p. 65).

\section{Analisis Kelayakan Model}

Setelah draf model dibuat maka hal selanjutnya adalah menganalis draf model permainan dengan berpatokan pada data yang berupa total skor yang diperoleh dari hasil penjumlahan skor item yang diberikan oleh ahli melalui observasi terhadap model permainan. Model yang disusun dianggap layak untuk diujicobakan dengan skala kecil maupun skala besar secara kuantitatif dihitung skor mencapai standar minimal kelayakan. Norma kategorisasi yang akan digunakan sesuai dengan ketentuan Azwar (2003, p. 109) sebagai berikut:

Tabel 1. Pedoman Konversi Nilai Kelayakan Model

\begin{tabular}{cc}
\hline Formula & Kategori \\
\hline $\mathrm{X}<(\mu-1,0 \sigma)$ & Kurang \\
$(\mu-1,0 \sigma) \leq X<(\mu+1,0 \sigma)$ & Cukup \\
$(\mu+1,0 \sigma) \leq X$ & Baik \\
\hline
\end{tabular}

Keterangan:

$\mathrm{X}=$ jumlah skor subjek

$\mu=$ mean ideal

$=$ jumlah item $\mathrm{x}\left(\frac{\text { skor tertinggitskor terendah }}{2}\right)$

$\sigma=$ standar devisiasi ideal

$=1 / 6[$ (jumlah aitem $\mathrm{x}$ skor tertinggi)-(jumlah aitem $\mathrm{x}$ skor terendah)]

\section{Uji Efektivitas}

Metode

Setelah produk yang dibuat dan ditetapkan sebagai produk akhir, maka selanjutnya dilakukan uji efektifitas produk akhir. Adapun nama dari produk akhir adalah model "Permainan Perseptual Motorik" yang di dalamnya terdapat enam aktivitas permainan, yaitu: (1) permainan karung berantai, (2) permainan egrang berantai, (3) permainan engklek berantai, (4) permainan balok berantai, (5) permainan kelereng berantai, dan (6) permainan ban berantai. Uji efektifitas produk diakhir dilakukan menggunakan lembar observasi berupa tes penilai hasil belajar siswa. Instrumen ini digunakan untuk mengetahui keeefktifan produk dari sisi ranah afektif (perilaku sosial), ranah kognitif, dan ranah psikomotor (kesadaran arah, kesadaran ruang, kesadaran tempo, koordinasi dan keseimbangan).

Metode yang digunakan dalam uji efektifitas produk akhir ini adalah eksperimen. (Sugiyono, 2008, p. 501). Sukmadinata (2013, p. 208) design pretest-posttest satu kelompok adalah:

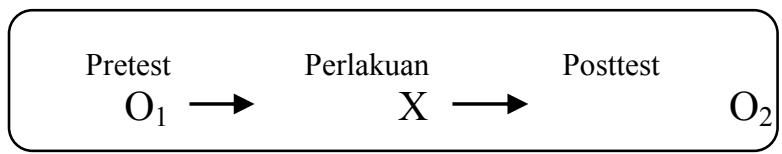

Setelah diketahui hasil dari pretest dan posttest dari hasil pengamatan berdasarkan lembar penilaian atau rubrik penilaian, maka langkah selanjutnya dianalisis. Adapun langkahlangkah dalam menganalisis hasil pembelajaran permainan sederhana melalui permainan berantai, sebagai berikut: (a) masing-masing item hasil observasi direkapitulasi berdasarkan aktivitas yang dilakukan siswa, (b) menghitung jumlah skor masing-masing siswa, (c) setelah diperoleh hasil dari skor awal dan skor akhir selanjutnya skor dirubah menjadi nilai, (d) selanjutnya dihitung selisih antara nilai pretest dan nilai posttets untuk mendapatkan nilai Gain (gain value). Rumus yang digunakan dalam menghitung nilai Gain (Meltzer, 2002, p. 1260) adalah:

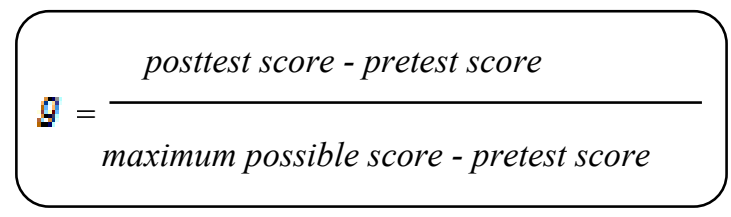

(e) Selanjutnya menentukan kategori analisis peningkatan ranah afektif, kognitif, dan psikomotor berdasarkan efektifitas pembelajaran dapat dijelaskan pada tabe 2l. Hake (1998, p. 66) menyatakan kriteria perolehan skor N-Gain.

Tabel 2. Kriterian Gains Standard

\begin{tabular}{cc}
\hline Gain yang diperoleh & Kategori \\
\hline $\mathrm{G} \geq 0,7$ & Tinggi \\
$0,3<\mathrm{g} \leq 0,7$ & Sedang \\
$\mathrm{G} \leq 0,3$ & Rendah \\
\hline
\end{tabular}

Selanjutnya untuk membuktikan signifikansi peningkatan hasil efektifitas produk akhir dari permainan sebagai aktivitas pembel-ajaran dengan materi permainan sederhana pada siswa Sekolah Dasar kelas bawah dengan Uji t menggunakn SPSS 16.0 for windows. Penggunaan Uji $\mathrm{t}$ sebelumnya harus dilakukan uji prasarat, yaitu uji normalitas dan uji homogenitas. 


\section{HASIL DAN PEMBAHASAN}

\section{Hasil}

Validasi dilakukan oleh tiga validator yaitu ahli dibidang pembelajara motorik, ahli materi penjas, dan praktisi penjas SD. Hasil validasi yang telah dilakukan oleh tiga orang ahli akan dituangkan kedalam bentuk Tabel 3 .

Tabel 3. Hasil Validasi Draf Awal Ahli \& Praktisi Terhadap Model Permainan

\begin{tabular}{ccccc}
\hline Permainan & Ahli 1 & Ahli 2 & Praktisi & Hasil \\
\hline Estafet Karung & Baik & Baik & Baik & Baik \\
Estafet Egrang & Baik & Baik & Baik & Baik \\
Estafet Engklek & Baik & Baik & Baik & Baik \\
Estafet Balok & Baik & Baik & Baik & Baik \\
Estafet Kelereng & Baik & Baik & Baik & Baik \\
Estafet Ban & Baik & Baik & Baik & Baik \\
\hline
\end{tabular}

Berdasarkan Tabel 3, maka dapat dinyatakan bahwa semua model permainan dinyatakan baik dengan revisi. Oleh karena itu, model permainan siap dilanjutkan untuk diujicobakan pada uji skala kecil. Tahap uji coba skala kecil dilakukan dengan 27 siswa di SD N Ambarukmo dengan 1 orang guru sebagai pelaksana pembelajaran. Selanjutnya setelah dilakukan penilaian melalui skala nilai terhadap permainan selanjutnya akan disajikan pada Tabel 4.

Tabel 4. Hasil Validasi Skala Kecil Ahli \& Praktisi Terhadap Model Permainan

\begin{tabular}{lllll}
\hline Permainan & Ahli 1 & Ahli 2 & Praktisi & Hasil \\
\hline Estafet Karung & Baik & Baik & Baik & Baik \\
Estafet Egrang & Baik & Baik & Baik & Baik \\
Estafet Engklek & Baik & Baik & Baik & Baik \\
Estafet Balok & Baik & Baik & Baik & Baik \\
Estafet Kelereng & Baik & Baik & Baik & Baik \\
Estafet Ban & Baik & Baik & Baik & Baik \\
\hline
\end{tabular}

Berdasarkan Tabel 4, maka dapat dinyatakan bahwa semua model permainan dinyatakan baik dengan revisi. Oleh karena itu, model permainan siap dilanjutkan untuk diujicobakan pada uji skala besar. Tahap uji coba skala Besar dilakukan dengan 32 siswa di SD N Ngringin \& SD N Puren dengan 2 orang guru sebagai pelaksana pembelajaran. Selanjutnya setelah dilaku- kan penilaian melalui skala nilai terhadap permainan selanjutnya akan disajikan pada Tabel 5 .

Berdasarkan Tabel 5, maka dapat dinyatakan bahwa semua model permainan dinyatakan baik dengan revisi. Oleh karena itu, model permainan siap dilanjutkan diujicobakan pada uji efektifitas. Adapun hasil uji t berdasarkan Tabel 6.

Tabel 5. Hasil Validasi Skala Besar Ahli \& Praktisi Terhadap Model Permainan

\begin{tabular}{llllll}
\hline Permainan & Ahli 1 & Ahli 2 & Praktisi & Praktisi & Hasil \\
\hline Karung Berantai & Baik & Baik & Baik & Baik & Baik \\
Egrang Berantai & Baik & Baik & Baik & Baik & Baik \\
Engklek Berantai & Baik & Baik & Baik & Baik & Baik \\
Balok Berantai & Baik & Baik & Baik & Baik & Baik \\
Kelereng Berantai & Baik & Baik & Baik & Baik & Baik \\
Ban Berantai & Baik & Baik & Baik & Baik & Baik \\
\hline
\end{tabular}
Berdasarkan uji efektifitas pada Tabel 6, maka dapat dinyatakan bahwa model permainan dapat dinyatakan efektif untuk meningkatkan: (1) afektif (perilaku sosial: tanggung jawab, kerjasama, dan toleransi), (2) kognitif, dan (3) psikomotor (perseptual motorik: kesadaran arah, kesadaran ruang, kesadaran tempo, koordinasi, dan keseimbangan). Jika nilai signifikansi kurang dari 0,05 maka ada perbedaan antara sebelum dan sesudah perlakuan. Jika nila $\mathrm{t}$ negatif maka nilai posttest lebih besar dari nilai pretest, dan jika nilai t positif maka nilai posttest lebih kecil dari nilai pretest.

\section{Hasil Produk Akhir}

\section{Pelaksanaan Permainan Karung Berantai}

Tujuan permainan untuk meningkatkan (1) kesadaran arah, (2) kesadaran ruang, (3) kesadaran tempo, (4) koordinasi, (5) keseimbangan, (6) tanggung jawab, (7) kerja sama, (8) toleransi. (9) pemahaman terhadap aturan permainan, (10) pemahaman terhadap arahan guru. Alat yang digunakan yaitu karung goni sebanyak 4 karung, modifikasi alat agility ledder sebanyak 4 alat, penanda/cone (botol mineral bekas) sebanyak 6 penanda/cone per-lintasan, kapur serbuk, meteran $50 \mathrm{~m}$ dan papan nama permainan.

Tabel 6. Hasil Uji t terhadap Model Permainan

\begin{tabular}{lccccc}
\hline \multicolumn{1}{c}{ Permainan } & $\begin{array}{c}\text { Afektif } \\
\text { (perilaku sosial) }\end{array}$ & $\begin{array}{c}\text { Kognitif } \\
(\mathbf{t})\end{array}$ & $\begin{array}{c}\text { Psikomotor } \\
\text { (Perseptual Motorik) (t) }\end{array}$ & Sig. & Ket. \\
\hline Karung Berantai & -15.509 & -14.165 & -13.263 & .000 & Efektif \\
Egrang Berantai & -15.065 & -12.506 & -16.891 & .000 & Efektif \\
Engklek Berantai & -12.306 & -12.506 & -12.300 & .000 & Efektif \\
Balok Berantai & -12.305 & -11.489 & -11.927 & .000 & Efektif \\
Kelereng Berantai & -12.496 & -11.182 & -13.313 & .000 & Efektif \\
Ban Berantai & -11.246 & -12.683 & -11.361 & .000 & Efektif \\
\hline
\end{tabular}




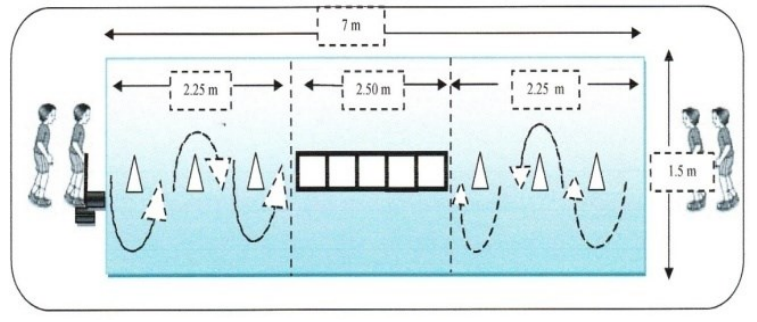

Gambar 1. Lintasan Permainan Karung Berantai

Anak dibagi menjadi empat kelompok, dengan jumlah kelompok yang sama rata yaitu empat anak perkelompok. Anak berbaris dengan rapi sesuai kelompoknya. Anak pertama menggunakan karung. Setelah ada aba-aba permainan dimulai, anak pertama melakukan lompat karung. Anak melewati penanda/cone dengan arah zig-zag, kemudiaan melompat melewati kotak secara berurutan tanpa keluar garis, selanjutnya anak melewati cone lagi dengan arah zig-zag. Anak pertama melepaskan karung, kemudian memberikan kepada anak kedua sebagai tanda pergantian. Anak kedua melakukan aktivitas yang sama seperti anak pertama, dan begitu seterusnya. Permainan ini dilakukan secara perlombaan dan secara estafet. Permainan berakhir ketika semua anak sudah mendapat giliran melakukan aktivitas permainan.

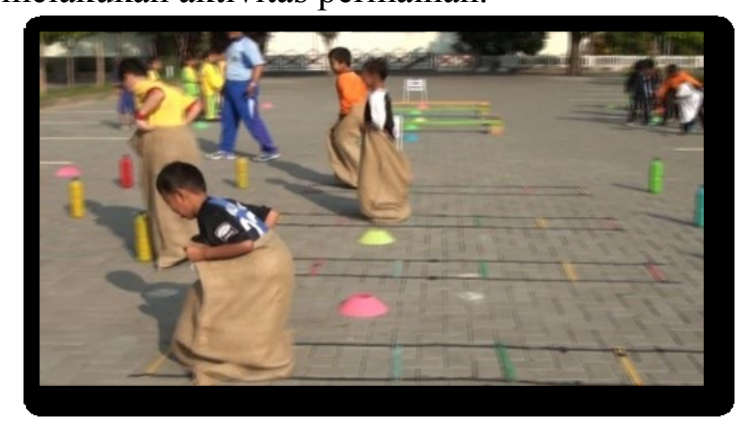

Gambar 2. Permainan Karung Berantai

Pelaksanaan Permainan Egrang Berantai

Tujuan permainan untuk meningkatkan (1) kesadaran arah, (2) kesadaran ruang, (3) kesadaran tempo, (4) koordinasi, (5) keseimbangan, (6) tanggung jawab, (7) kerja sama, (8) toleransi. (9) pemahaman terhadap aturan permainan, (10) pemahaman terhadap arahan guru. Alat yang digunakan yaitu egrang balok sebanyak 4 pasang egrang balok, modifikasi alat agility ledder sebanyak 4 alat, penanda/cone (botol mineral bekas) sebanyak 6 penanda/cone per-lintasan, kapur serbuk, meteran $50 \mathrm{~m}$, dan papan nama permainan.

Anak dibagi menjadi empat kelompok, dengan jumlah kelompok yang sama rata yaitu empat anak perkelompok. Anak pertama berdiri di atas egrang balok. Setelah ada aba-aba permainan dimulai, anak pertama mulai berjalan di atas egrang balok (kaki tidak boleh menyentuh tanah) sambil melewati penanda/cone dengan arah zig-zag. Kemudian anak berjalan melewati kotak secara berurutan menggunakan egrang balok, selanjutnya melewati penanda/cone lagi dengan arah zig-zag. Setelah itu anak memberikan egrang balok kepada anak kedua. Anak kedua melakukan aktivitas yang sama seperti anak pertama, dan begitu seterusnya. Permainan ini dilakukan secara perlombaan dan secara estafet. Permainan berakhir ketika semua anak sudah mendapat giliran melakukan aktivitas permainan.

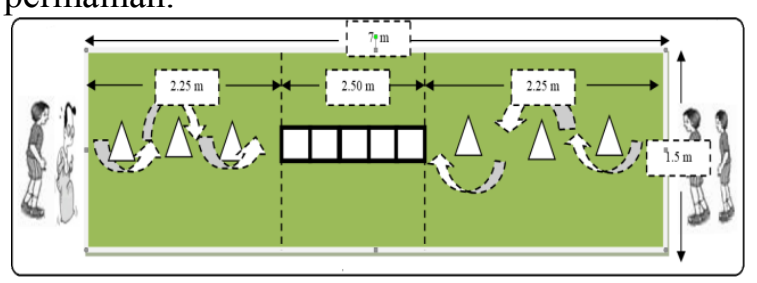

Gambar 3. Lintasan Permainan Egrang Berantai

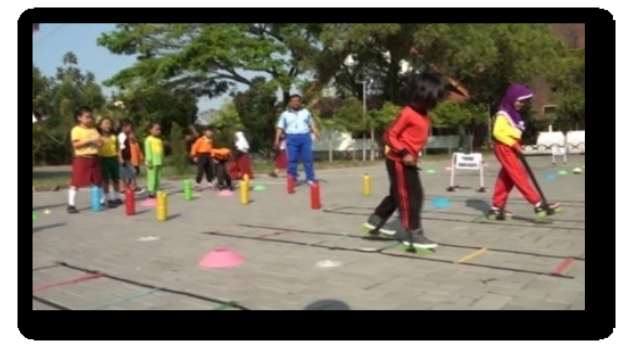

Gambar 4. Permainan Egrang Berantai

Pelaksanaan Permainan Engklek Berantai

Tujuan permainan untuk meningkatkan (1) kesadaran arah, (2) kesadaran ruang, (3) kesadaran tempo, (4) koordinasi, (5) keseimbangan, (6) tanggung jawab, (7) kerja sama, (8) toleransi. (9) pemahaman terhadap aturan permainan, (10) pemahaman terhadap arahan guru. Alat yang digunakan yaitu modifikasi alat agility ledder berbentuk engklek gunung sebanyak 4 engklek dan berbentuk engklek pesawat sebanyak 4 engklek, bola sebanyak 4 bola, dan kapur serbuk, meteran $50 \mathrm{~m}$, dan papan nama permainan.

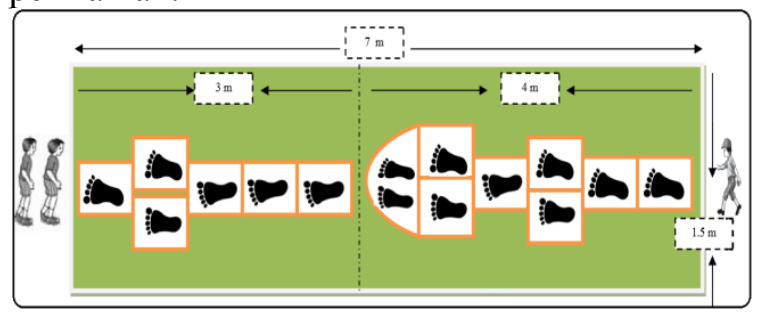

Gambar 5. Lintasan Permainan Engklek Berantai 
Anak dibagi menjadi empat kelompok, dengan jumlah kelompok yang sama rata yaitu empat anak tiap kelompok. Anak pertama memegang bola. Setelah ada aba-aba permainan dimulai, anak pertama berlari sambil membawa bola. Kemudian melewati engklek gunung dengan melompat (kaki kanan, kaki kanan, dua kaki, kaki kanan, dua kaki, dan dua kaki) ke arah depan melewati kotak secara berurutan tanpa keluar garis, kemudian melewati engklek pesawat dengan melompat (kaki kanan, kaki kanan, kaki kanan, dua kaki dan kaki kanan). Anak pertama memberikan bola kepada anak kedua sebagai tanda pergantian (bola tidak boleh dilempar). Anak kedua melakukan aktivitas yang sama seperti anak pertama dengan kaki sebaliknya, dan begitu seterusnya. Permainan ini dilakukan secara perlombaan dan secara estafet. Permainan berakhir ketika semua anak sudah mendapat giliran melakukan aktivitas permainan.

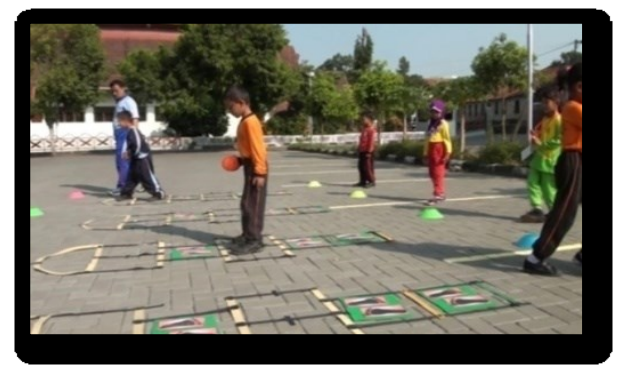

Gambar 6. Permainan Engklek Berantai

Pelaksanaan Permainan Balok Berantai

Tujuan permainan untuk meningkatkan (1) kesadaran arah, (2) kesadaran ruang, (3) kesadaran tempo, (4) koordinasi, (5) keseimbangan, (6) tanggung jawab, (7) kerja sama, (8) toleransi. (9) pemahaman terhadap aturan permainan, (10) pemahaman terhadap arahan guru. Alat yang digunakan yaitu balok kayu sebanyak 10 balok per-lintasan, papan titian sebanyak 4 papan titian, kapur serbuk, meteran $50 \mathrm{~m}$, dan papan nama permainan.

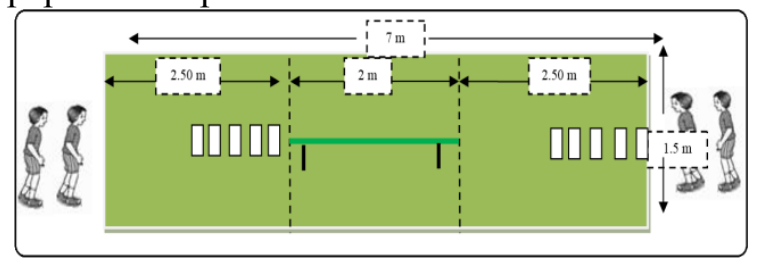

Gambar 7. Lintasan Permainan Balok Berantai

Anak dibagi menjadi empat kelompok, dengan jumlah kelompok yang sama rata yaitu delapan anak tiap kelompok. Masing-masing anak saling berpasangan di dalam kelompoknya.
Anak pertama berdiri di atas dua balok menghadap ke samping di belakang garis start sambil memegang satu balok, sedangkan anak kedua juga berdiri di atas dua balok tepat di samping anak pertama. Setelah ada aba-aba permainan dimulai, anak pertama meletakan balok yang dipegang ke tanah atau lantai, kemudian berjalan menyamping berpijak pada balok yang telah diletakan tadi (kaki tidak boleh menyentuh tanah, harus berpijak pada balok), kemudian anak kedua berjalan menyamping dan berpijak pada balok di samping anak pertama, selanjutnya anak kedua mengambil balok yang berada di belakangnya dan memberikan kepada anak pertama, begitu seterusnya aktivitas yang dilakukan. Kemudian anak pertama berjalan di papan titian sambil merentangkan tangan, disusul anak kedua. Selanjutnya anak pertama dan anak kedua mengambil balok lagi yang telah disediakan, dan mulai melakukan lagi aktivitas seperti yang pertama, kemudian memberikan balok tersebut kepada anak selanjutnya. Anak selanjutnya melakukan aktivitas yang sama, begitu seterusnya. Permainan ini dilakukan secara perlombaan dan secara estafet. Permainan berakhir ketika semua anak sudah mendapat giliran melakukan aktivitas permainan.

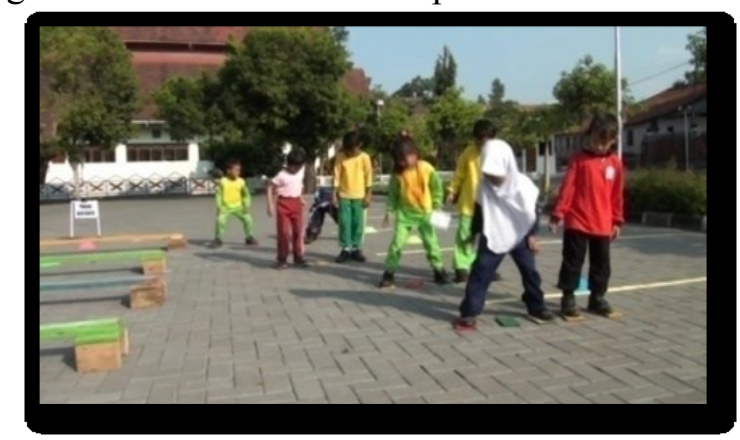

Gambar 8. Permainan Balok Berantai

\section{Pelaksanaan Permainan Kelereng Berantai}

Tujuan permainan untuk meningkatkan (1) kesadaran arah, (2) kesadaran ruang, (3) kesadaran tempo, (4) koordinasi, (5) keseimbangan, (6) tanggung jawab, (7) kerjasama, (8) toleransi. (9) pemahaman terhadap aturan permainan, (10) pemahaman terhadap arahan guru. Alat yang digunakan yaitu papan titian sebanyak 4 papan titian untuk 4 lintasan, cone/penanda, kelereng sebanyak 8 kelereng, sendok sebanyak 8 sendok, ember sebanyak 8 ember, keranjang sebanyak 12 keranjang, bola warna-warni sebanyak 24 bola, kapur serbuk, meteran $50 \mathrm{~m}$, dan papan nama permainan. 


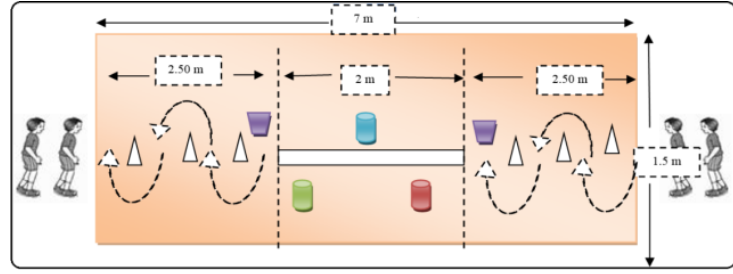

Gambar 9. Lintasan Permainan Kelereng Berantai

Anak dibagi menjadi empat kelompok, dengan jumlah kelompok yang sama rata yaitu empat anak tiap kelompok. Anak pertama yaitu memegang sendok yang berisikan kelereng. Setelah ada aba-aba permainan dimulai, anak pertama berjalan dengan arah zig-zag melewati penanda sambil membawa sendok yang berisikan kelereng, setelah itu anak mengambil ember yang berisikan bola warna warni, kemudian mulai berjalan di atas papan sambil membawa ember yang berisikan bola warna warni, dan memasukan bola tersebut ke dalam keranjang sesuai warna keranjang. Selanjutnya mengambil sendok dan kelereng lagi yang telah disediakan, anak berjalan dengan arah zig-zag melewati penanda sambil membawa sendok yang berisikan kelereng. Kemudian anak pertama menuangkan kelereng kesendok yang telah dipegang anak kedua. (Catatan: ketika anak pertama memberikan/menuangkan kelereng ke sendok anak kedua, kelereng tidak boleh jatuh). Anak kedua melakukan aktivitas seperti yang dilakukan anak pertama, dan begitu seterusnya. Permainan berakhir ketika semua anak sudah mendapat giliran melakukan aktivitas permainan.

\section{Pelaksanaan Permainan Ban Berantai}

Tujuan permainan untuk meningkatkan (1) kesadaran arah, (2) kesadaran ruang, (3) kesadaran tempo, (4) koordinasi, (5) keseimbangan, (6) tanggung jawab, (7) kerja sama, (8) toleransi. (9) pemahaman terhadap aturan permainan, (10) pemahaman terhadap arahan guru. Alat yang digunakan yaitu ban (std 80/90) sebanyak 4 ban, penanda/cone (botol mineral bekas) ) sebanyak 4 penanda/cone per-lintasan, kapur serbuk, meteran $50 \mathrm{~m}$, dan papan nama permainan.

Anak dibagi menjadi empat kelompok, dengan jumlah kelompok yang sama rata yaitu empat anak tiap kelompok. Anak pertama memegang ban. Setelah ada aba-aba permainan dimulai, anak pertama mulai mengelindingkan ban menggunakan tangan sambil melewati conecone dengan arah zig-zag. (Catatan: ban tidak boleh diangkat, tetapi digelindingkan) Setelah itu anak pertama memberikan ban ke anak kedua. Anak kedua melakukan aktivitas yang sama seperti anak pertama, dan begitu seterusnya. Permainan berakhir ketika semua anak sudah mendapat giliran melakukan aktivitas permainan.

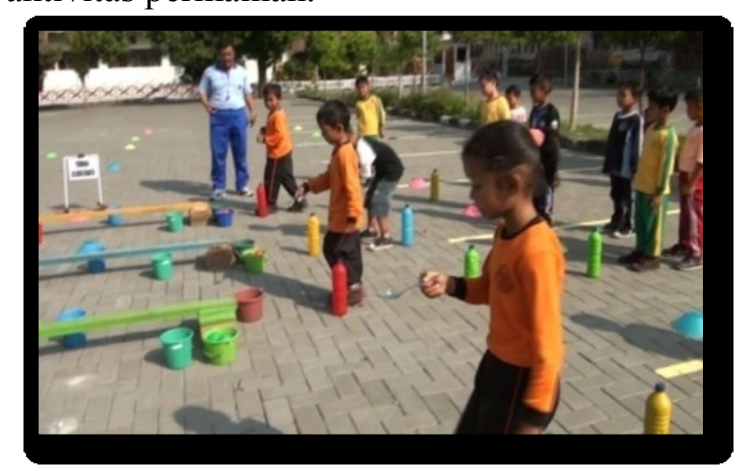

Gambar 10. Permainan Kelereng Berantai

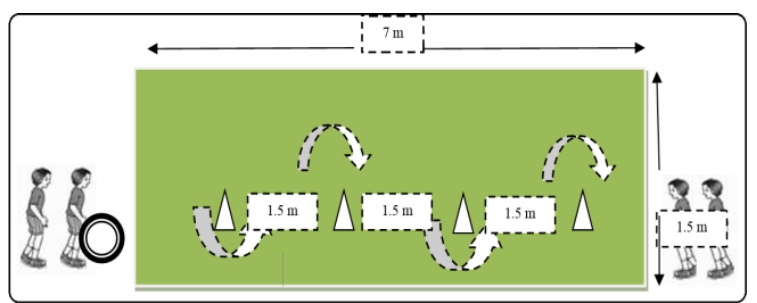

Gambar 11. Lintasan Permainan Ban Berantai

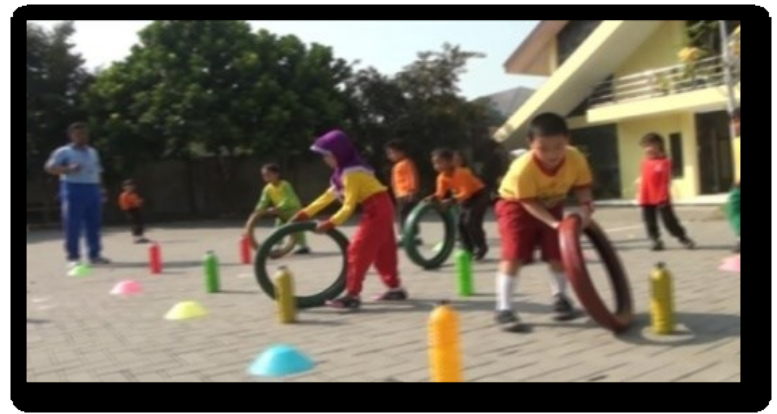

Gambar 12. Permainan Ban Berantai

\section{SIMPULAN DAN SARAN}

\section{Simpulan}

Pengembangan model permainan ini menghasilkan enam macam bentuk permainan yang dituangkan dalam bentuk buku pedoman dan DVD (Digital Video Disc), aktivitas permainan meliputi: (1) permainan karung berantai, (2) permainan egrang berantai, (3) permainan engklek berantai, (4) permainan balok berantai, (5) permainan kelereng berantai, dan (6) permainan ban berantai, keenam permainan sesuai dengan karakteristik perkembangan gerak lokomotor yang meliputi jalan, lari, dan lompat untuk siswa sekolah dasar kelas bawah. 


\section{Jurnal Keolahragaan 5 (2), September 2017 - 181}

Nurul Fajar Muslimah Ningrum, Pamuji Sukoco

Berdasarkan hasil uji lapangan maka model permainan dinyatakan layak dari segi isi materi mencakup SK dan KD, kesesuaian tujuan penelitian, sarana dan prasarana meliputi kemudahan memperoleh, keamanan, dan kenyaman, bahasa mencakup penjelasan model permainan, serta format penulisan mencakup kesesuaian tampilan model permainan.

Model permainan yang dikembangakan efektif untuk meningkatkan perseptual motorik yang meliputi kesadaran arah, kesadaran ruang, kesadaran tempo, koordinasi, keseimbangan, dan perilaku sosial yang meliputi tanggung jawab, kerjasama, toleransi.

\section{Saran}

Saran pemanfaatan produk yaitu bagi siswa, agar terus belajar dan meningkatkan kemampuan yang berhubungan dengan perseptual motorik. Hal ini berkaitan dengan pentingnya kemampuan perseptual motorik terhadap keberhasilan dibidang akademik, kehidupan sehari-hari, dan belajar gerak/kompetisi olahraga. serta lebih meningkatkan perilaku-perilaku sosial, yang berguna sebagai jembatan berinteraksi dengan masyarakat luas. Bagi guru yang menjadi uji coba perlu menggunakan model permainan dalam pelaksanaan pembelajaran penjas. Bagi guru yang belum menggunakan model permainan perlu menguji cobakan terlebih dahulu untuk melihat apakah model permainan cocok untuk diterapkan. Praktisi atau guru ketika akan menggunakan produk ini sebagai media pembelajaran, disarankan terlebih dahulu membaca buku atau menonton video (DVD) panduan model permainan. Bagi peneliti disarankan perlu menambah jumlah subjek yang lebih banyak untuk memperkuat penelitian. Bagi akademisi selanjutnya, perlu adanya kajiankajian dan pengembangan-pengembangan lebih lanjut untuk menambah khasanah permainan untuk perseptual motorik, agar dapat menunjang proses belajar dan bermain untuk siswa sekolah dasar kelas bawah yang sesuai dengan kurikulum yang berlaku. Selain itu perlu ditambah penelitian yang sesuai dan penambahan jumlah sampel.

Diseminasi penyebarluasan produk pengembangan yaitu perlu adanya sosialisasi dan kajian lebih dalam di waktu mendatang terkait model permainan untuk meningkatkan perseptual motorik dan perilaku sosial. Diperlukan pengembangan model permainan lainnya, misalnya berdasarkan kecabangan untuk siswa kelas atas dalam memenuhi kebutuhan siswa.

\section{DAFTAR PUSTAKA}

Allahyari, T., Rangi, N. H., Khosravi, Y., \& Zayeri, F. (2009). Development and evaluation of a new questionnaire for rating of cognitive failures at work. International Journal of Occupational Hygiene, 3(1), 6-11. Retrieved from http://ijoh.tums.ac.ir/index.php/ijoh/article /view/26

Azwar, S. (2003). Penyusunan skala psikologi. Yogyakarta : Pustaka Pelajar. https://doi.org/2003

Azwar, S. (2007). Reliabilitas dan validitas. Yogyakarta: Pustaka Pelajar.

Brinkman, W.-P. (2009). Design of a questionnaire instrument. In Handbook of Mobile Technology Research Methods (pp. 31-57). London: Nova Publisher. Retrieved from http://mmi.tudelft.nl/ willempaul/WP_Papers_online_versie/Design_of _a_questionnaire_Instrument_preliminary _version.pdf

Gabbard, C., LeBlanc, E., \& Lowy, S. (1994). Physical education for children: Building the foundation. Englewood: Prentice-Hall.

Gall, M. D., Gall, J. P., \& Borg, W. R. (2007). Educational research: An introduction. Boston: Pearson/Allyn \& Bacon.

Gallahue, D. L., Ozmun, J. C., \& Goodway, J. (2012). Understanding motor development: Infants, children, adolescents, adults. New York, NY.: McGraw-Hill.

Hake, R. R. (1998). Interactive-engagement versus traditional methods: A sixthousand-student survey of mechanics test data for introductory physics courses. American Journal of Physics, 66(1), 6474. https://doi.org/10.1119/1.18809

Juniarta, T., \& Siswantoyo, S. (2014). Pengembangan model permainan rintangan (handicap games) untuk latihan kebugaran jasmani anak usia 10-12. Jurnal Keolahragaan, 2(1), 88-105. https://doi.org/10.21831/JK.V2I1.2606

Meltzer, D. E. (2002). The relationship between mathematics preparation and conceptual learning gains in physics: A possible hidden variable" in diagnostic pretest 
scores. American Journal of Physics, $70(12)$, https://doi.org/10.1119/1.1514215. 1259-1268.

Mohnsen, B. S. (2008). Teaching middle school physical education: A standards-based approach for grades 5-8. Human Kinetics.

Rosalie, S. M., \& Müller, S. (2012). A model for the transfer of perceptual-motor skill learning in human behaviors. Research Quarterly for Exercise and Sport, 83(3), 413-421.

https://doi.org/10.1080/02701367.2012.10 599876

Rosdiani, D. (2012). Model pembelajaran langsung dalam pendidikan jasmani dan kesehatan. Bandung: Alfabeta.
Sugiyono. (2008). Metode penelitian bisnis. Bandung: Pusat Bahasa Depdiknas. Badung: Pusat Bahasa Depdiknas.

Sugiyono. (2010). Metode penelitian kuantitatif kualitatif dan $R \& D$. Bandung: Alfabeta.

Sukmadinata, N. S. (2013). Metode penelitian pendidikan. Bandung: PT Remaja Rosdakarya.

Tseng, M. H., \& Murray, E. A. (1994). Differences in perceptual-motor measures in children with good and poor handwriting. The Occupational Therapy Journal of Research, 14(1), 19-36. https://doi.org/10.1177/153944929401400 102. 